\title{
ALTERATIONS OF LIPID LEVELS MAY INDUCE THE INSULIN RESISTANCE IN TYPE TWO DIABETES MELLITUS: A SYSTEMIC REVIEW
}

\author{
DIVYA JYOTHI P' ${ }^{1}$ DOONDI PHANI KUMAR N ${ }^{2 *}$, VINAY MOHAN A², RAMYA A ${ }^{2}$
}

${ }^{1}$ Department of Pharmacy Practice, Nirmala College of Pharmacy, Atmakur, Andhra Pradesh, India. ${ }^{2}$ Department of Pharmacy Practice, Pharm D Students, Nirmala College of Pharmacy, Atmakur, Andhra Pradesh, India. Email: phani.krishna.07.97@gmail.com

Received: 23 December 2019, Revised and Accepted: 24 January 2020

\begin{abstract}
Diabetes mellitus (DM) is not one disorder; it represents a series of metabolic conditions related to hyperglycemia and caused by defects in hormone secretion and hormone action. Exposure to chronic hyperglycemia may result in microvascular complications in the retina (diabetic retinopathy), kidney (diabetic nephropathy), neuron (diabetic-neuropathy), skin, foot, and cardiac complications (stroke, hypertension...etc.). International Diabetes Federation estimates that 1.1 million children and adolescents aged 14-19 years have type one DM. Without interventions to halt the increase in diabetes, there will be at least 629 million people living with diabetes by 2045. In the body, white adipose tissue is the leading site for the storage of excess energy produced from the food intake in large quantities, of the development of insulin resistance (IR) and type 2 DM by the over intake of fatty acid in the body. It results in the accumulation of fatty acyl co-A (FA-CoA) within the myocytes. It leads to improper signaling of the insulin and reduces the level in the myocytes and pancreases beta cells. It combines with genetically reduces the expression of peroxisome proliferator-activated receptorgamma (PPAR- $\gamma$ ) coactivator-1, initiates the inflammation process by the activation of the tumor necrotic factor alpha and protein kinase C. These alterations lead to further increase the intramyocellular FA-CoA and triglycerides. The sequence of events may develop mitochondrial dysfunction in the sarcolemma outer layers. Finally improves IR also with increasing intramyocellular lipids. This concept might be helpful to those who are pursuing endocrinology specialization, nursing staff, pharmacists, and other medical departments.
\end{abstract}

Keywords: Diabetes mellitus, Hyperglycemia, Essential fatty acids, Lipid metabolism, Expression of peroxisome proliferator-activated receptorgamma coactivator, Fatty acyl co-A, Triglycerides, Insulin resistance.

(C) 2020 The Authors. Published by Innovare Academic Sciences Pvt Ltd. This is an open access article under the CC BY license (http://creativecommons. org/licenses/by/4. 0/) DOI: http://dx.doi.org/10.22159/ajpcr.2020.v13i3.36672

\section{INTRODUCTION}

Diabetes mellitus (DM) is not one disorder; it represents a series of metabolic conditions related to hyperglycemia and caused by defects in hormone secretion and hormone action. Exposure to chronic hyperglycemia may result in microvascular complications in the retina (diabetic retinopathy [DR]), kidney (diabetic nephropathy), neuron (diabetic-neuropathy), skin complications, foot complications, and causes cardiac complications (stroke, hypertension...etc.) [1]. It comes from the Greek language, which means (Gr. Passing through) [2] DM was portrayed 3000 years before the old Egyptians. The expression "diabetes" was first-authored by Aratus of Cappadocia (81-133AD). Afterward, the word mellitus (nectar sweet) was included by Thomas Willis (Britain) in 1675 after rediscovering the sweetness of pee and blood of patients (first seen by the old Indians). It was distinctly in 1776 that Dobson (Britain) right off the bat affirmed the nearness of abundance sugar in urine and blood as a reason for their sweetness. In the current time, the historical backdrop of diabetes corresponded with the development of an exploratory drug. A significant achievement in the historical context of diabetes is the foundation of the job of the liver in glycogenesis, and the idea that diabetes is because of overabundance glucose generation Claude Bernard (France) in 1857. Mering and Makowski found the role of the pancreas in the pathogenesis of diabetes (Austria) in 1889 [3]

Most of the epidemiological examinations report the general predominance of diabetes without recognizing. Despite the benefit of subtyping is the examination of the individuality of condition. Subtyping type one diabetes mellitus (T1DM) and type two diabetes mellitus (T2DM) in the populace concentrates achievable utilizing as often as possible accessible clinical data [4,5] A few investigations have revealed. The populace pervasiveness of different types of diabetes, for example, monogenic diabetes [6,7] and diabetes because of pancreatic infection [8]. Grouping of diabetes type is especially critical for frequency. It also observes in thinner people from low- and middle-income countries such as India [8], and among people of Indian descent living in high-income nations $[9,10]$ diabetes found in every population in the world and all regions, including rural parts of low- and middle-income countries. The number of people with diabetes is gradually rising, with the World Health Organization (WHO) estimating there were 422 million adults with diabetes worldwide in 2014. The age-adjusted prevalence in adults rose from $4.7 \%$ in 1980 to $8.5 \%$ in 2014 , with the most considerable rise in low- and middle-income countries compared to high-income countries [11]. Moreover, the International Diabetes Federation estimates that 1.1 million children and adolescents aged 14-19 years have T1DM [12]. Without interventions to halt the increase in diabetes, there will be at least 629 million people living with diabetes by 2045 .

\section{TYPES OF DIABETES}

Diabetes can be incorporating into the two types.

1. Diabetes insipidus (Type I insulin non-dependent).

2. DM (Type II insulin-dependent).

\section{DIABETES INSIPIDUS}

Type 1 diabetes (earlier called insulin-dependent or juvenile diabetes) typically diagnosed in infants and young adults, but it can occur at any age [13]. Type 1 diabetes is an immune system disease where the $\beta$-cells of the pancreas do not deliver adequate insulin, a hormone which enables users to (glucose) for vitality. The cells become kept from energy and glucose be abundant in the blood. DM is then trailing by perilous states of hypoglycemia (low glucose) and hyperglycemia (high glucose). 
At the point when hypoglycemia creates, cells do not get enough glucose, and patients endure perplexity, loss of awareness, and trancelike state. Indeed, even passing can results when the mind is concerning glucose for a long time. Hyperglycemia and delayed nonattendance of insulin may indicate ketoacidosis, which is the aggregation of ketones in the blood when the body uses fat for vitality rather than glucose because unsaturated lipids cannot be changed over into glucose at a constant state. Ketones compose the blood acidic and close all body roles. Likewise indicates a state of extreme torpidity and in a long time declining [14-19].

\author{
Symptoms [20] \\ - Polyuria \\ - Polydipsia \\ - Polyphagia \\ - Unexplained weight loss \\ - Numbness in extremities \\ - Dysesthesias (pain in feet) \\ - Recurrent or severe infections \\ - Loss of consciousness or severe nausea/vomiting or coma
}

\section{Pathophysiology}

T1DM is the after effect of a blend of hereditary and ecological impacts. It most ordinarily results from the immune system obliteration of insulindelivering $\beta$-cells in the pancreas. Eisenbarth recommended that at least one environmental variable, for example, enteroviruses, dietary components, or poisons, may trigger the advancement of T-cell secondary autoimmunity in hereditarily helpless individuals [21]. Autoimmunity is showed by discernible antibodies to ICA512/IA-2, insulin autoantibody, and glutamic acid decarboxylase. Insulitis with slow $\beta$-cell obliteration prompts pre-diabetes lastly to manifest $\mathrm{DM}$. These patients are vulnerable to other immune system ailments, for example, Hashimoto's thyroiditis, celiac illness, Addison's sickness, and myasthenia gravis. Different ancestral loci in the significant histocompatibility (human leukocyte antigen) [22] locale are associated with expanded defencelessness to creating T1DM, including the alleles DR3/4, DQ 0201/0302, DR 4/4, and DQ $0300 / 0302$. The danger of T1DM is roughly $5 \%$ if there is an influenced first-degree relative and somewhat higher if the affected parent is the dad instead of the mother. Continuous research by universal systems is investigating approaches to avert, deferral or turn around the movement of T1DM (for example, Trial Net, TRIGR) [23].

\section{Screening}

The American Diabetes Association (ADA), as of late, adjusted their rules to suggest screening for islet autoantibodies in high hazard people [24]. More recently, professional organizations, including the ADA, have recommended the use of the hemoglobin $\mathrm{A} 1 \mathrm{c}(\mathrm{HbA} 1 \mathrm{c})$ for the diagnosis of diabetes. The HbA1c test should be performed using a method that is certified by the National Glycohemoglobin Standardization Program (NGSP) and standardized according to the diabetes control and complications trial (DCCT) (Table 1) [25].

\section{DIABETES MELLITUS/T2DM}

It as maturity-onset DM, there is no loss of moderate reduction in the beta-cell mass, insulin in circulation is shallow [28]. Incessant fuel surfeit is the essential pathogenic occasion that drives the improvement of type 2 diabetes in hereditarily and epigenetically powerless individuals $[29,30]$ T2DM is most common in adults, but an increasing number of children and adolescents are also affected [31]

\section{Symptoms [32]}

- Symptoms for years before being diagnosed

- May also experience numbness in extremities

- Pain in feet

- Blurred vision

- May have recurrent or severe infections.
Pathophysiology

T2DM is an insulin-obstruction condition with related beta-cell brokenness. At first, there is a compensatory increment in insulin discharge, which keeps up glucose levels in a typical range. As the condition advances, beta cells change, and insulin discharge cannot keep up glucose homeostasis, delivering high glucose. A large portion of the patients with T2DM are stout or have higher muscle versus fat ratio, appropriated transcendently in the stomach district. This fatty tissue itself advances insulin obstruction through different inflammatory mechanisms, including expanded free fatty acid (FFA) discharge and adipokine malfunction. Inadequacy of physical activity, preceding gestational DM (GDM) in those with hypertension or dyslipidemia, enhances the chance of getting T2DM. Developing information proposes a job for adipokine dysregulation, irritation anomalous incretin science with diminished incretins, for example, glucagon-like peptide-1 or incretin obstruction, hyperglucagonemia, expanded renal glucose reabsorption, and variations from the norm in gut microbiota [33]

\section{Screening}

The best test for diabetes, the fasting plasma glucose (FPG), is likewise a segment of the symptomatic test. FPG examination and the 75-g oral galactose tolerance test (OGTT) are both reasonable tests for diabetes; nevertheless, the FPG test is favored in clinical settings since it is simpler and quicker to perform, progressively helpful and worthy to patients, and more affordable. An FPG $126 \mathrm{mg} / \mathrm{dl}(7.0 \mathrm{mmol} / \mathrm{l})$ is a sign for retesting, which ought to be rehashed on an alternate day to affirm a conclusion. If the FPG is $<126 \mathrm{mg} / \mathrm{dl}(7.0 \mathrm{mmol} / \mathrm{l})$ and there is a high doubt for diabetes, an OGTT ought to perform. A 2-h post-load, an incentive in the OGTT $200 \mathrm{mg} / \mathrm{dl}(11.1 \mathrm{mmol} / \mathrm{l})$, is a positive test for diabetes and ought to affirm on an alternative day,

Table 1: The American Diabetes Association, as of late, adjusted their rules to prescribe screening for islet autoantibodies in diagnosis guidelines[26] and from type 1 diabetes treatment and guidelines [27]

\begin{tabular}{|c|c|c|}
\hline Test & Results & Interpretation \\
\hline \multirow[t]{3}{*}{$\mathrm{HbA} 1 \mathrm{c}^{1}$} & $\geq 6.5 \%$ & Diabetes \\
\hline & $5.7-6.4 \%$ & $\begin{array}{l}\text { Impaired glucose } \\
\text { tolerance }\end{array}$ \\
\hline & $\leq 5.7 \%$ & Normal \\
\hline \multirow[t]{3}{*}{$\begin{array}{l}\text { Fasting plasma } \\
\text { glucose }^{3}\end{array}$} & $\begin{array}{l}\geq 126 \mathrm{mg} / \mathrm{dL} \\
(7.0 \mathrm{mmol} / \mathrm{L})\end{array}$ & Diabetes \\
\hline & $100-125 \mathrm{mg} / \mathrm{dL}$ & $\begin{array}{l}\text { Impaired glucose } \\
\text { tolerance }\end{array}$ \\
\hline & $\leq 100 \mathrm{mg} / \mathrm{dL}$ & Normal \\
\hline \multirow{4}{*}{$\begin{array}{l}\text { 2-h plasma glucose } \\
\text { during an OGTT } \\
\text { Random plasma } \\
\text { glucose or patients } \\
\text { with classic symptoms } \\
\text { of hyperglycemic crisis }\end{array}$} & $\begin{array}{l}\geq 200 \mathrm{mg} / \mathrm{dL} \\
(11.1 \mathrm{mmol} / \mathrm{L})\end{array}$ & Diabetes \\
\hline & $\begin{array}{l}\geq 200 \mathrm{mg} / \mathrm{dL} \\
(11.1 \mathrm{mmol} / \mathrm{dL})\end{array}$ & Diabetes \\
\hline & $140-199 \mathrm{mg} / \mathrm{dL}$ & $\begin{array}{l}\text { Impaired glucose } \\
\text { tolerance }^{1}\end{array}$ \\
\hline & $\leq 140 \mathrm{mg} / \mathrm{dL}$ & Normal \\
\hline
\end{tabular}

${ }^{1}$ The examination should be performed in a laboratory using a method that is NGSP approved and regulated to the DCCT assay. ${ }^{2}$ IGT is like IFG but is diagnosed with an independent OGTT. Both IGT and IFG are opportunity factors for prospective diabetes and cardiovascular diseases. They are seldom joint related to as pre-diabetes. Group Health recommends avoiding the term pre-diabetes because not all patients with IGT and IFG will develop diabetes. ${ }^{3}$ Fasting is defined as no calorie intake for at least $8 \mathrm{~h} .{ }^{4}$ The examination should be conducted as reported by the WHO using a glucose load-receiving the equivalent to $75 \mathrm{~g}$ of anhydrous glucose dissolved in water. IGT: Impaired glucose tolerance, IFG: Impaired fasting glucose, OGGT: Oral galactose tolerance test 
This examination demands the use of a glucose load-receiving the equivalent of $75 \mathrm{~g}$ anhydrous glucose dissolved in water: 2-h PG, 2-h post-load glucose (Table 2).

\section{GDM}

During a healthy pregnancy, an active insulin resistance (IR) creates starting around mid-pregnancy and advances during the third trimester [35]. Hormones and adipokines discharged from the placenta, including necrotic tumor necrotic factor (TNF)- $\alpha$, human placental lactogen, and human placental development hormone are potential reasons for IR in pregnancy. Likewise, expanded estrogen, progesterone, and cortisol during IR pregnancy add to an interruption of the glucose-insulin balance [36]. To make up for the fringe during pregnancy, insulin discharge increments from a lady's pancreas.

The improvement of GDM happens when a lady's pancreas does not emit enough insulin to stay aware of the metabolic worry of the IR. Moreover, expanded maternal fat affidavit, diminished exercise, and expanded caloric admission add to this condition of relative glucose bigotry [36]. In early pregnancy increases the insulin secretions, while insulin sensitivity is consistent, lowered, or may increase. At the mid of the pregnancy insulin sensitivity starts to decline progressively, and became worse during the rest of the pregnancy, being worst in the late third trimester and disappear, GDM usually develops in the late second trimester and disappears, instantly, post-delivery [36].

\section{Symptoms [37]}

- Recurrent infections

- Blurred vision

- Tiredness

- Needing to urinate frequently.

\section{Pathophysiology}

Especially observed in second-trimester of the pregnancy women. The significant donors are the placental hormones human placental lactogen, progesterone, cortisol, development hormone, and prolactin. These hormones cause diminished phosphorylation of insulin receptor substrate and, in this way, significant insulin opposition. Cytokines like tissue corruption factor has likewise in the pathogenesis of insulin obstruction. Coherently, the pancreas ought to make up for this interest by expanding insulin discharge. Notwithstanding, in GDM, there is a weakening of $\beta$ cell work, especially the main stage of insulin discharge.

In an investigation on Latino ladies with GDM, $67 \%$ decrease of $\beta$ cell capacity noted when contrasted with the ordinary pregnant control. The second stage of insulin discharge is practically identical to that in the individual with ordinary glucose resilience. The deformities in $\beta$ cells have been ascribed either to immune system procedure or enzymatic imperfection like glucokinase. Autoimmunity ought to suspect in ladies who do not have ordinary qualities of the expanded danger of GDM, for example, who are lean and Caucasians. In this manner, the blend of insulin opposition and secretory deformity during pregnancy results in GDM [38-44]

Table 2: Displays the demonstrative criteria for diabetes. Fasting is characterized as no utilization of nourishment or drinks other than water for in any event $8 \mathrm{~h}$ before testing [34]

\begin{tabular}{lll}
\hline Normoglycemia & IFG or IGT & Diabetes* $^{*}$ \\
\hline $\mathrm{FPG}<100 \mathrm{mg} / \mathrm{dL}$ & $\mathrm{FPG} \geq 100$ and & $\mathrm{FPG} \geq 126 \mathrm{mg} / \mathrm{dL}$ \\
& $<126 \mathrm{mg} / \mathrm{dL}$ (IFG) & \\
$2-\mathrm{h} \mathrm{PG}^{+}<140 \mathrm{mg} / \mathrm{dL}$ & $\begin{array}{l}2-\mathrm{hPG}^{+} \geq 140 \text { and } \\
\end{array}$ & $2-\mathrm{h} \mathrm{PG}^{+} \geq 200 \mathrm{mg} / \mathrm{dL}$ \\
& $<200 \mathrm{mg} / \mathrm{dL}$ (IGT) & \\
\hline
\end{tabular}

${ }^{+} \mathrm{p}<0.05$. Symptoms of diabetes and casual plasma glucose concentration of $\geq 200$ $\mathrm{mg} / \mathrm{dL} .{ }^{*}$ In the inadequacy of unambiguous hyperglycemia, an examination of diabetes must be approved, on the following day, by measurement of FPG, 2-h PG, or random plasma glucose (if symptoms are present). The FPG test is sufficient preferred because of the efficiency of treatment, accessibility, acceptability to patients, and lower expenses. Fasting is defined as no caloric intake for at least $8 \mathrm{~h}$

\section{Screening}

Standard OGTT is doing at 24-28 weeks after a medium-term quick (fasting plasma glucose and plasma glucose $2 \mathrm{~h}$ after $75 \mathrm{~g}$ glucose drink). A 2-h level $>7.8 \mathrm{mmol} / \mathrm{L}$ (or $140 \mathrm{mg} / \mathrm{dL}$ ) is demonstrative of gestational diabetes. If fasting and post-prandial blood sugars are raising in the primary trimester, this may demonstrate previous DM (which is the view as an alternate condition, with different results) [45].

\section{OTHER TYPES OF DM}

\section{Monogenic diabetes}

Since the last WHO characterization of diabetes [46], there have been significant advances in characterizing. The fundamental sub-atomic hereditary qualities that can help recognize specific subtypes of diabetes. These advances have uncovered clinical subgroups that are genetically heterogeneous and have brought about the acknowledgment new hereditary disorders. The most significant development has been that genetic determination can result. In improved treatment results for specific individuals, yet a little extent of the all outnumber of individuals with diabetes. As a result, genetic testing has received for chosen subgroups of individuals as a guide to clinical administration in certain nations.

A straightforward way to deal with a grouping of monogenic subtypes of diabetes utilizes the quality image of the changed quality pursued by the clinical disorder [47]. For example, a child diagnosed with permanent neonatal DM (PNDM) because of a transformation in KCNJ11 is marked as having KCNJ11 PNDM. If there is a clinical conclusion of PNDM; however, a quality change had not been searched for nor discovered, at that point, an individual would be ordered as PNDM as it was.

\section{Juvenile diabetes}

Juvenile diabetes commits to diabetes in blooming. Type 1 diabetes affects $90 \%$ of the people younger than 25 who have diabetes. It is the most common metabolic disorder in young. There is no accepted meaning of what is anticipated by a younger person in this meaning; but, most people would notice in a young person as occurring under 16-18 years of age [48]. Clinical manifestations of monogenic defects in $\beta$-cell function include maturity-onset diabetes of the young (MODY), PNDM, transient neonatal diabetes, and genetic syndromes where insulin-deficient diabetes is associated with specific clinical features [49].

\section{TYPE 1.5 DIABETES/LADA}

The type 1.5 diabetes is a non-official term that is occasionally used to allude to a type of type 1 diabetes known as idle immune system diabetes in grown-ups (LADA). Type 1.5 diabetes is analyzed during adulthood, as is most instances of sort two diabetes. Type 1.5 diabetes additionally has a modest beginning, like sort 2 diabetes. Nevertheless, type 1.5 diabetes is an immune system illness like sort one diabetes and will practically inevitably require insulin at some point will in future [50].

\section{TYPE-3 DM (T3D)}

T3D is a neuroendocrine disorder that represents the progression of T2DM to Alzheimer's disease [51] T3D contributes to the increase of a total load of Alzheimer's patients worldwide. It also suggests that insulin-degrading enzyme could be significant who holds the capacity to shift type II DM to type III DM by altering the metabolic pathways such as regulation of beta-cell development negative regulation of P13K/AKT pathways and amyloid-beta degradation [52]

\section{MODY}

MODY is a form of diabetes classically characterized as having an autosomal dominant inheritance, onset before the age of 25 years in at least one family member and partly preserved pancreatic beta-cell role. The 14 capable genes are related to being MODY type 1-14, of which MODY 2 and three might be the most common forms. MODY could 
adequately hold characteristics of T2DM , which is of multifactorial causation [53].

\section{COMPLICATIONS OF DIABETES MELLITUS}

Diabetes is associated with several complications. Acute metabolic complexities associated with fatality include diabetic ketoacidosis from abnormally high blood glucose (hyperglycemia) concentration and coma as the effect of low blood glucose (hypoglycemia). The complications are wide-ranging and are expected at least in part to persistent elevation of blood glucose levels, which leads to the destruction of blood vessels. The complication is grouped under microvascular disease (due to damage to small blood vessels) and macrovascular disease (due to damage to the arteries). Microvascular complications include retinopathy, nephropathy, and neuropathy. Significant complications of macrovascular complexities incorporate accelerated cardiovascular disease (CVD) following in myocardial infarction and cerebrovascular disease manifesting as cerebrovascular strokes; other chronic complications of diabetes incorporate depression [54], dementia [55], and sexual dysfunction $[56,57]$.

\section{DIABETIC NEPHROPATHY}

Diabetics nephropathy represents the primary cause of end-stage renal failure in western societies [58]. The development of proteinuria clinically characterizes it with a subsequent decrease in glomerular filtration rate, which progresses over a long period, often over 10-20 years. If left untreated, the resulting uremia is fatal [59], kidney disease is also a significant risk factor for the development of macrovascular complexities such as heart attacks, strokes [60], and hypertension [61].

\section{DR}

DR is characterized by a spectrum of lesions within the retina and is the leading cause of blindness among adults aged 20-74 years [62,63]. These incorporate changes in vascular permeability, capillary microaneurysms, capillary destruction, and excessive formation of new blood vessels. The neuronal retina is also dysfunctional with the destruction of some cells, which modifies retinal electrophysiology and appears in an inability to distinguish colors.

\section{DIABETES NEUROPATHY}

Diabetic neuropathy is a syndrome which comprises both the somatic and autonomic divisions of the peripheral nervous system. Half of the patients with diabetes finally develop neuropathy [64], with an existing prospect of one or more lower extremity amputations considered in some states to be up to $15 \%$. The neuropathy is a significant factor in the impaired wound healing, erectile dysfunction, and cardiovascular dysfunction seen in diabetes [65].

\section{CVD}

There is an extended risk of CVD in diabetes, such that an individual with diabetes has a risk of myocardial infraction equivalent to that of non-diabetic individuals who have previously had a myocardial infarction [66]. CVD considers for more than half of the fatality seen in diabetic people [67] and diabetes equate to an approximately threefold increased risk of myocardial infarction compared with the general population [68]. Normally, typ -2 diabetes is also called as the insulinindependent diabetes because based on their pathogenesis. It is a metabolic syndrome, and it also caused by different multifactor (Fig. 1).

\section{ESSENTIAL FATTY ACIDS}

Dietary essential fatty acids supply the nutrients and lipids to the body. Those also play a primary function in the body for energy production, growth, cellular metabolism, and muscle activity. The specific components of fats are necessary for the proper growth and development in animals, and humans were introduced in the 1930s (Burr and Burr,1929). These fatty acids are mainly required for hormone synthesis like estrogen; progesterone and thermogenesis also serve as the indispensable dietary precursors for the formation of proteinoids and other eicosanoids. The eicosanoid has provided more considerable significance to the study of their role in health and disease conditions. The eicosanoids are powerful autocrine and paracrine regulators of cell and tissue functions, i.e., thrombocyte aggregation, and provocative reactions, leukocyte functions, blood pressure, bronchial constriction, uterine constriction, vasoconstriction, and vasodilation of blood vessels.

Essential fatty acids are essential for lipid metabolism. The dietary fatty acids are also affecting cholesterol metabolism throughout life in the body. The primary source of essential fatty acids in the food chain is the ${ }^{*}$ Terrestrial, marine plants, and phytoplankton. The fish and other marine animals can elongate and desaturate the parent essential fatty acids and finally forming the long-chain polyunsaturated fatty acids (LCPUFAs). (Sprecher, 1981; Willis, 1984; Simopoulos, 1991)

In animals and humans' tissues, especially the liver tissues, can further elongation and desaturating the parent essential fatty acids. In normal conditions, the PUFAs promote fatty acid oxidation of normal levels of FFAs in the blood and in the case of n-3 LCPUFAs decreases the very-low-density lipoproteins (VLDL) secretion from the liver. For this mechanism, some fatty acids promote or inhibit the process of peroxisomal proliferation by the peroxisome proliferator-activated receptor (PPAR) (Masataka et al.,1997; Schoonjans et al., 1996). In some of the individuals, the intake of fatty acids contains more amount of saturated fat and a double bond, or trans fatty acids affect the PPAR activity. Hence, it prevents fatty acid oxidation by preventing the biosynthesis of LCPUFAs from parent-FFAs [69].

\section{CIRCULATING FATTY ACIDS MEDIATE IR}

It is difficult to identify the mediators, cause IR, but now one most important mediator was identified, i.e., FFAs. This hypothesis, that excess of circulating fatty acids mediate IR and strong correlation with obesity in animals and humans [70-72]. Furthermore, the deposition of fatty acids into non-adipose fat stores like muscle induces IR [73-77].

\section{ANOTHER HYPOTHESIS}

The excess circulating FFAs activate the toll-like receptors (TLRs) mainly TLR2 and TLR4. These two receptors are also already in the adipose tissue and with macrophages. Whenever the circulating FFAs activate the TLR2 and TLR4, promote the inflammatory changes with macrophages. These inflammatory signals suppress insulin signaling in myocytes that lead to IR in myocytes [78-81]. From the research, the mutation in TLR4 prevents diet-induced obesity and IR in mice [82]. Based on two, this hypothesis confirms that the increased intake of essential fatty acids leads to IR in skeletal muscle. It leads to type 2 diabetes by combining with genetically and environmental factors (Fig. 2).

\section{DYSLIPIDEMIA}

The quantitative and qualitative abnormalities of lipid lipoproteins in the body. This condition is characterized by the raised triglyceride levels, low high-density lipoproteins (HDL)-cholesterol levels and increases the accumulation of the VLDL, LDL, and cholesterolenrichment lipoprotein particles [83-85].

Dyslipidemia is an essential component of the IR syndrome and types two DM. In the animal and humans, the dyslipidemia condition can occur by changes, mainly

a. White adipose tissue

b. Apolipoproteins.

\section{White adipose tissue}

In humans, the adipose tissue plays an essential role as a master regulatory tissue in controlling whole-body lipid flux by maintaining both glucose and lipid homeostasis. In the body, white adipose tissue 


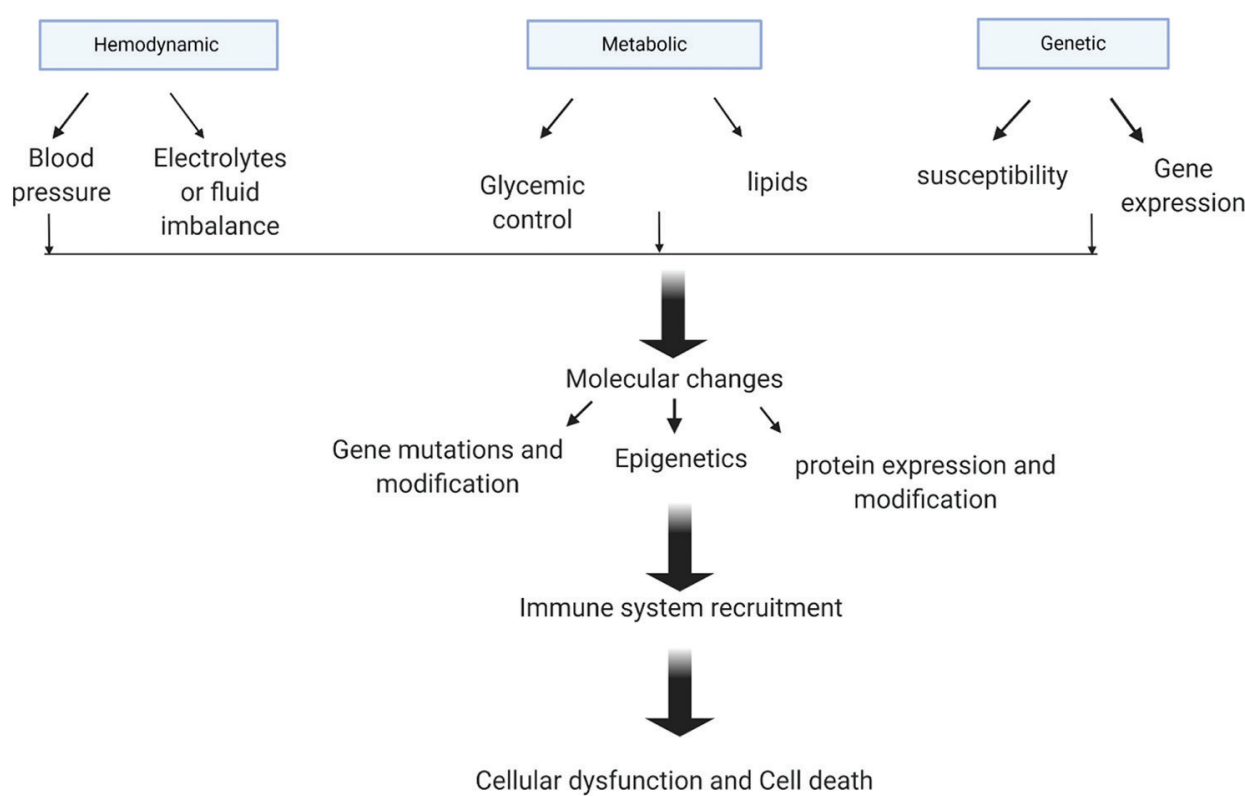

Fig. 1: Schematic overview of the significant areas contributing to diabetic complications

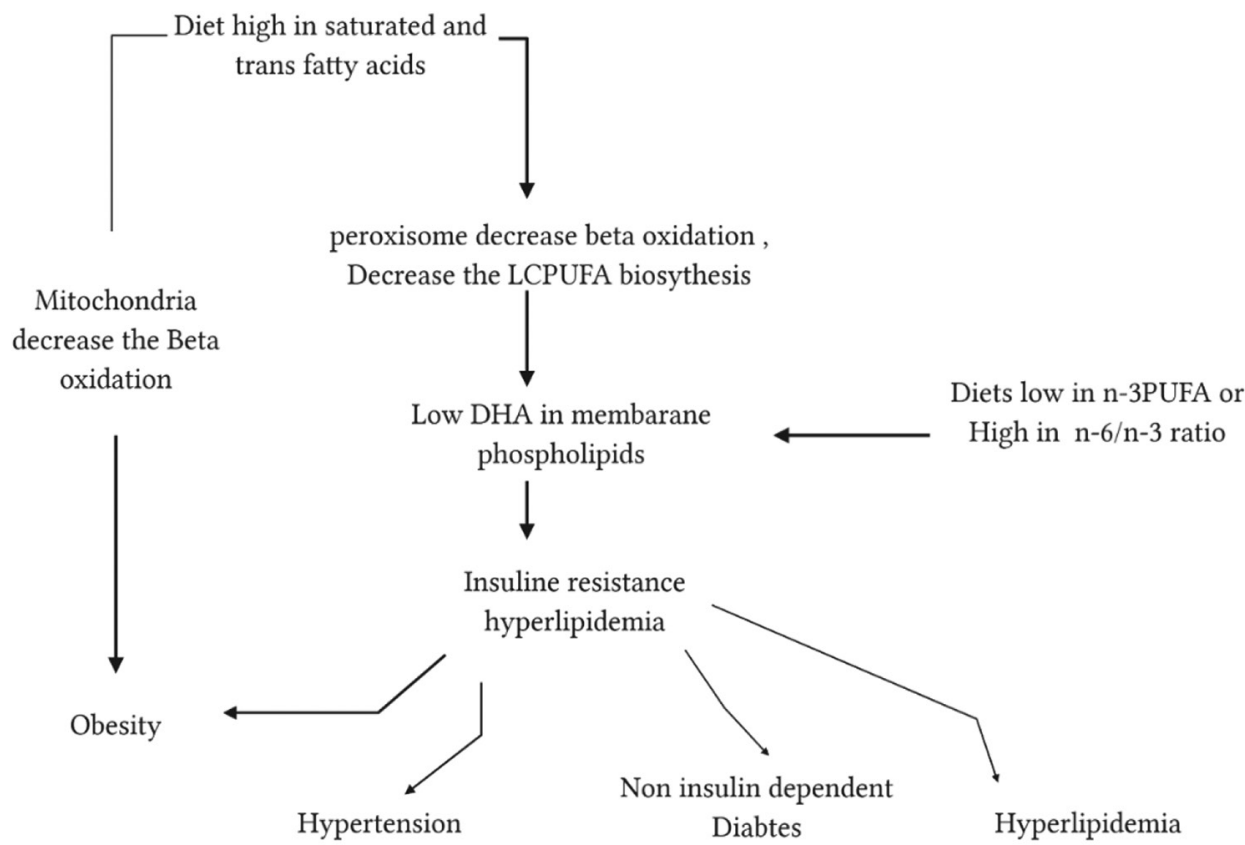

Fig. 2: The effects of excess dietary fatty acids, it is present in the body. These fatty acids decrease the beta-oxidation and long-chain polyunsaturated fatty acids) synthesis in adipose tissue, decrease the beta-oxidation in mitochondria of the sarcolemma. These alter causes obesity, hyperlipidemia, hypertension, and Type 2 diabetes mellitus. In developing countries, the population mostly takes the excess amount of vegetable oils, mainly sunflower oil, and corn oils. These oils contain an excess amount of lactic acidosis, it leads to may decrease the formation of DHA from a-linolenic acid [LNA $(18: 3, n-3)]$ since the delta- 6 desaturates is inhibited by an excess substrate

is the leading site for the storage of excess energy produced from the food intake in large quantities [86,87]. In white adipocytes, the energy is concentrated as the triglycerides (TG), like in a single large lipid droplet. In fasting conditions, these TG undergo rapidly hydrolyzed by lipases (this process is called lipolysis) and produce the fatty acids are transported to other tissues to be oxidized mainly in mitochondria for energy production [88]. In healthy conditions, during the fasting states, the tissues maintain equilibrium between the release of fatty acids into the circulations from the adipose tissues to their uptake and oxidation by the peripheral tissues like skeletal muscle. In human's larger intake of the calories, there is a change in the anatomical and physiological changes in the adipose tissue, i.e., size of adipocytes, release, and use fatty acids.

In the lean state, fatty acyl-CoA (FA-CoA) enzyme levels are within the muscle cells produce in the required quantity for rapid oxidation in mitochondria (Fig. 3a). In hyperplasia-induced obesity, as the caloric intake increases, so the adipocytes are enlarged because of the increasing amount of TG stores in humans and mice $[89,90]$. In the early stages, fatty acid levels can rise, but the skeletal muscle maintains high insulin sensitivity (Fig. 3b) [91-93] 


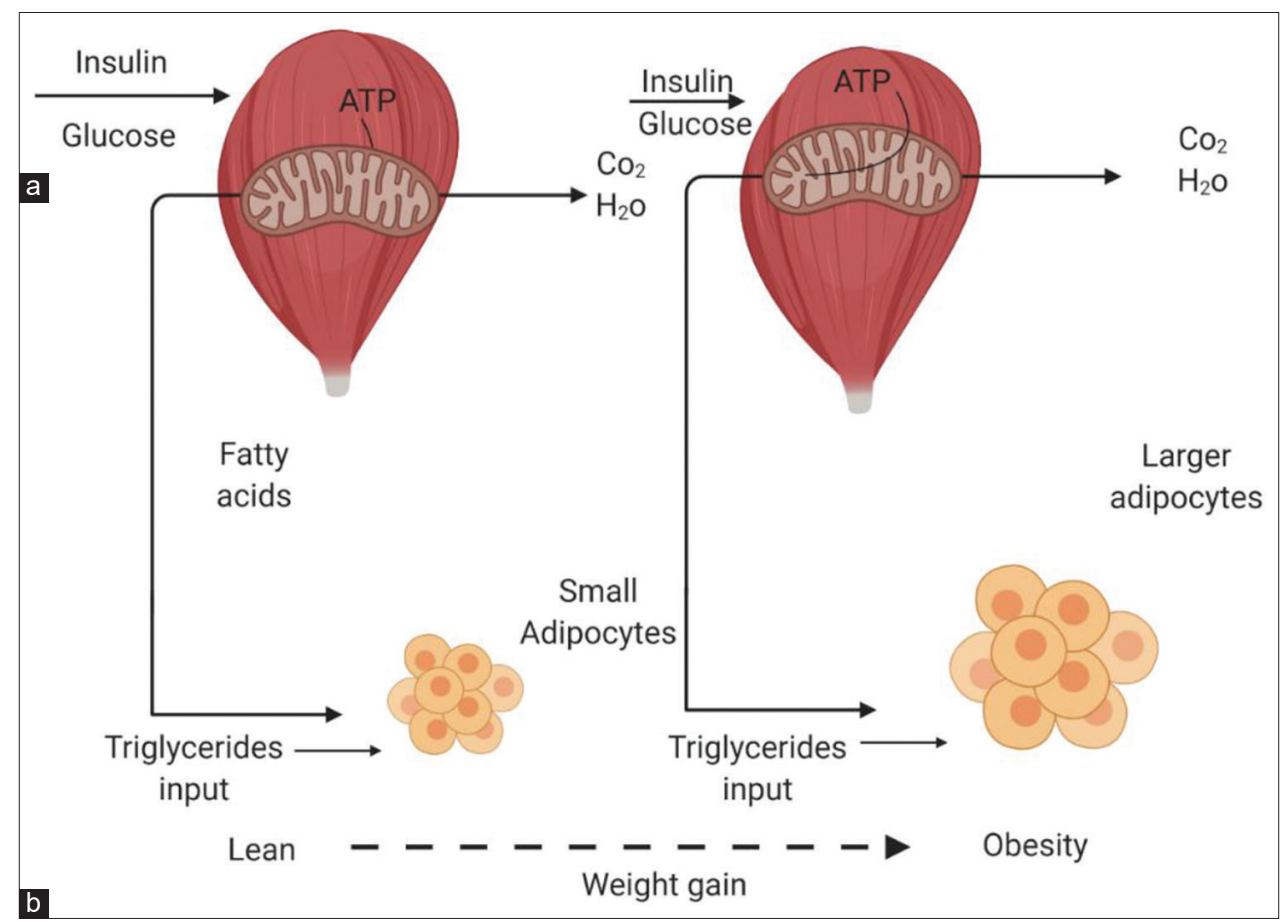

Fig. 3: (a and b) Adipose tissue triggers the insulin resistance in skeletal muscle

As the TGs a level are increase in adipose cells, it leads to acts as the endocrine cell and promotes various biological proteins and affects their metabolism and functions. In a few cases, there is an extension in fats but not adipose tissue. Hence, it promotes the elevated circulating TG and fatty acids. Finally, it leads to IR and combines with obesity causes type 2 diabetes. These altered functions have induced the synthesis of the VLDL in the liver also decreases the production of the HDL. It results in IR in the skeletal muscle and atherosclerosis disease; obesity finally types 2 diabetes in mice and humans [94-97].

\section{Apolipoproteins (apoE)}

The main two apolipoproteins are apo and apoB play an important role in the lipoprotein metabolism in liver tissue. The apoE protein necessary required for the metabolism of VLDL to IDL and LDL [98]. From other cellular and animal studies, reported that an apoE plays significant roles, those are

A. It also mediates the direct hepatic clearance of VLDL, HDL, and their remnants Fr example, LDL-R and lipoprotein receptor-related protein [98-102]. The main function is modifying the breakdown of lipoproteins that contains apoB, HDL metabolism, and TG secretion in all humans and animals [99,103-107].

B. ApoE is readily exchangeable between VLDL and HDL lipoproteins and transferred from HDL to TG-rich lipoproteins [108]. The process is called lipolysis by lipoprotein and hepatic lipases but depends on cholesterol and TG clearance. The lipoprotein lipase activity is inversely correlated with IR [109]. From in vitro studies prove that the ApoE increases the HDL levels in the liver by promoting the cholesterol efflux from peripheral cells to the liver [110]. This apolipoprotein acts as the direct anti-atherogenic by activating antioxidant activity and inhibits the platelet aggregation through the nitric oxide pathway and also acts as the anti-inflammatory activity [111-113]. The activity of apoE decreases in the body leads to metabolic changes and IR [83-85,114].

\section{OBESITY}

Obesity is defined as unnecessary fat deposition in the body. The body mass index (BMI) is a popular indicator of obesity [115]. BMI is $>30 \mathrm{~kg} / \mathrm{m}$ square and is considered as obesity. Obesity is caused by the mainly genetically and imbalance between feeding and physical activity. This factor plays a chief role in the pathogenesis of T2DM and CVDs. The relationship between obesity and T2DM has been known for many years, and it is the primary etiology of T1DM in $60-90 \%$ of patients [116].

However, obesity in humans is not the main factor in the diabetic state, also with other factors such as genetics and environmental factors. Obesity triggers metabolic syndrome, which can be characterised by the appearance of three out of five criteria, the criteria are abdominal (visceral obesity), increased plasma TG, decreased HDL cholesterol, elevated blood pressure, and plasma glucose levels in the body $[117,118]$. The metabolic syndrome is closely related to the IR in the peripheral tissues.

The inbred mouse strains research, reports the metabolic changes to occur when high-fat diet intake, which leads to obesity and causes IR. It leads to T2DM in mice and humans [119-121]. In humans being, obesity induces increases in circulating and sarcolemma fatty acids after this condition the elongation and desaturation of fatty acids in the outer layers of the sarcolemma in human skeletal muscle [117,122-124]. It develops the skeletal muscle IR (mostly depends on genetically), but it does not cause type 2 diabetes. Because the blood glycemia level can be maintained by compensatory metabolism, i.e. insulin secreted by the pancreatic beta cells. The failure of the insulin secretion from the pancreas's beta-cells leads to abnormal levels of glucose levels in the blood so in that condition develop T2DM [118,120-127].

The metabolism of amino acids occurs in the liver; the process is called gluconeogenesis. This pathway increases glucose levels, which promotes insulin secretion from the pancreas. Insulin growth factor -1 and insulin activate mTORC1 (mammalian target of rapamycin complex1 and S6K1 (ribosomal protein S6 kinase beta1) persist activation leads to serine phosphorylation of IR substrate (IRS-1 and IRS-2). It leads to IR develops. The prolongation of this condition leads to the negatively affect the function of islets, resulting in an impairing in insulin secretion leading to the onset of T2DM.

In the obesity condition, hyper aminoacidemia is the sign of increased IR. Insulin action is regulated by the branched-chain alpha-keto acid dehydrogenase complex, an enzyme complex involved in BCAA 


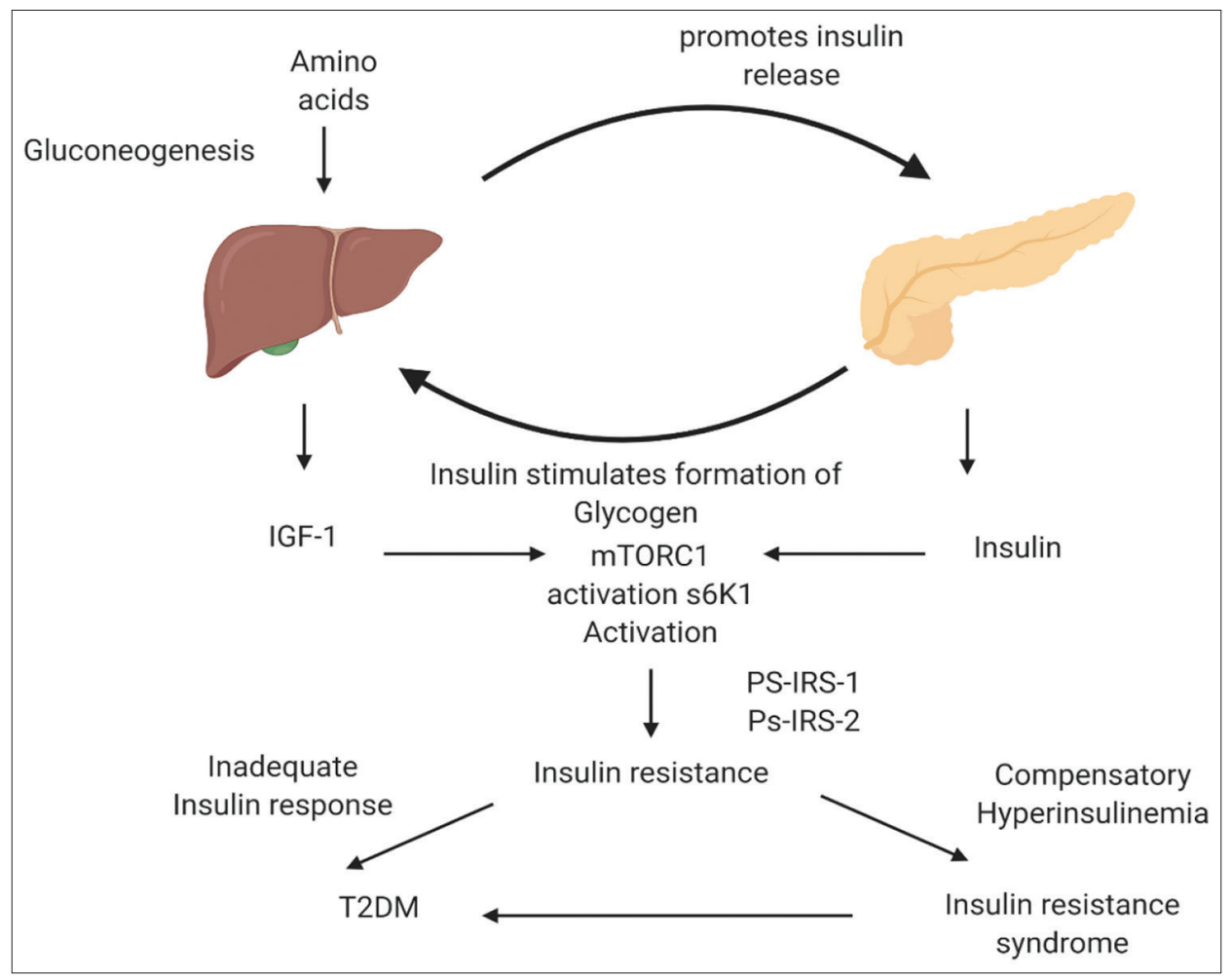

Fig. 4: Mechanism of the link between insulin resistance and T2D. IGF-1: Insulin-like growth factor; IRS: Insulin receptor substrate; mTORC1: Mammalian target of rapamycin complex 1; S6K1: Ribosomal protein S6 kinase beta1; T2D: Type 2 diabetes

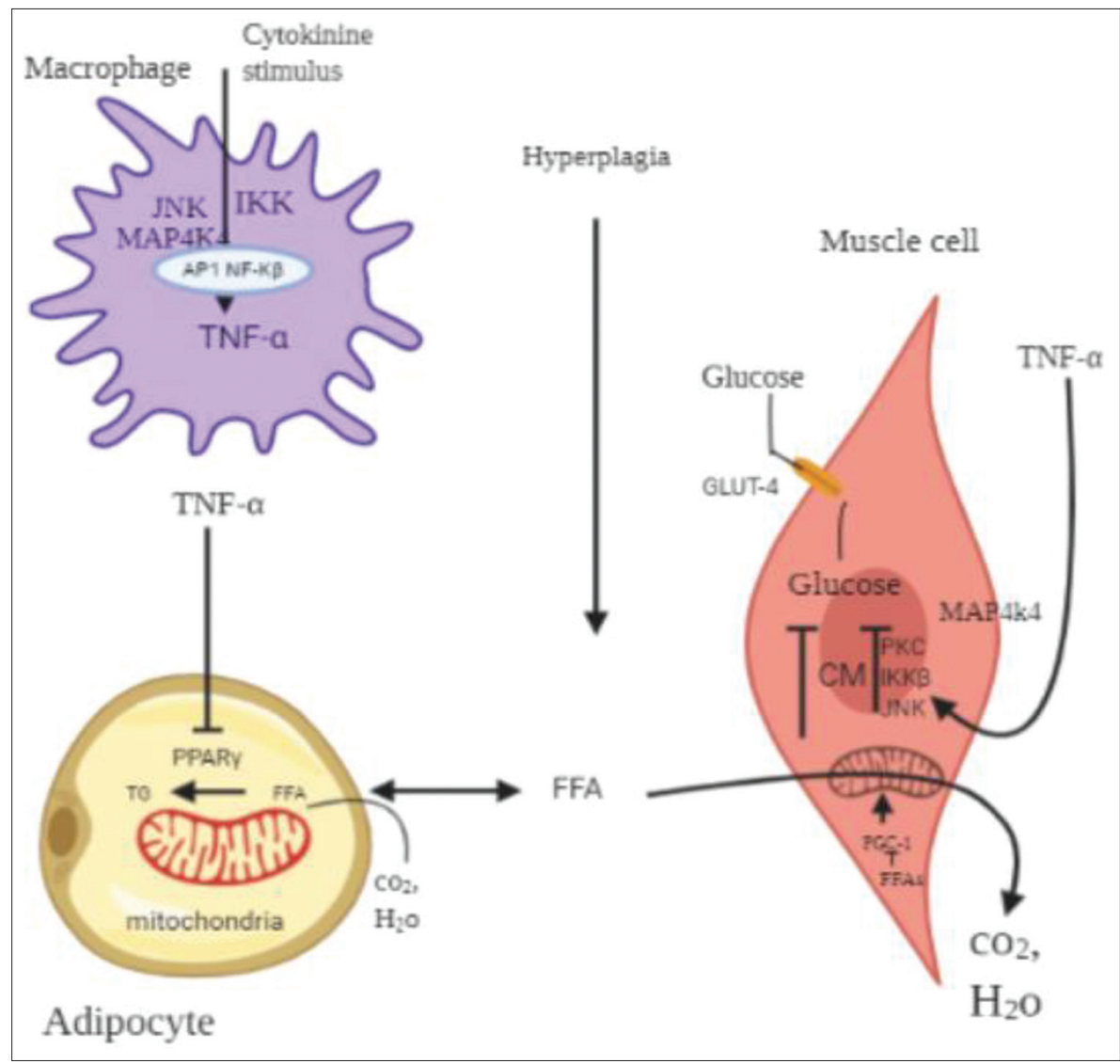

Fig. 5: The inflammation of adipose tissue and its effects. The overload of lipids in adipose tissue triggers the macrophage infiltration to produce a large amount of tumor necrotic factor-alpha through the Jun N-terminal kinase-activator protein-1 and mitogen-activated protein kinase kinase kinase kinase-4 signaling pathways. It causes mitochondrial dysfunction through the proliferative proliferatoractivated receptor-gamma (PPAR- $\gamma$ ) coactivator. It leads to insulin resistance 


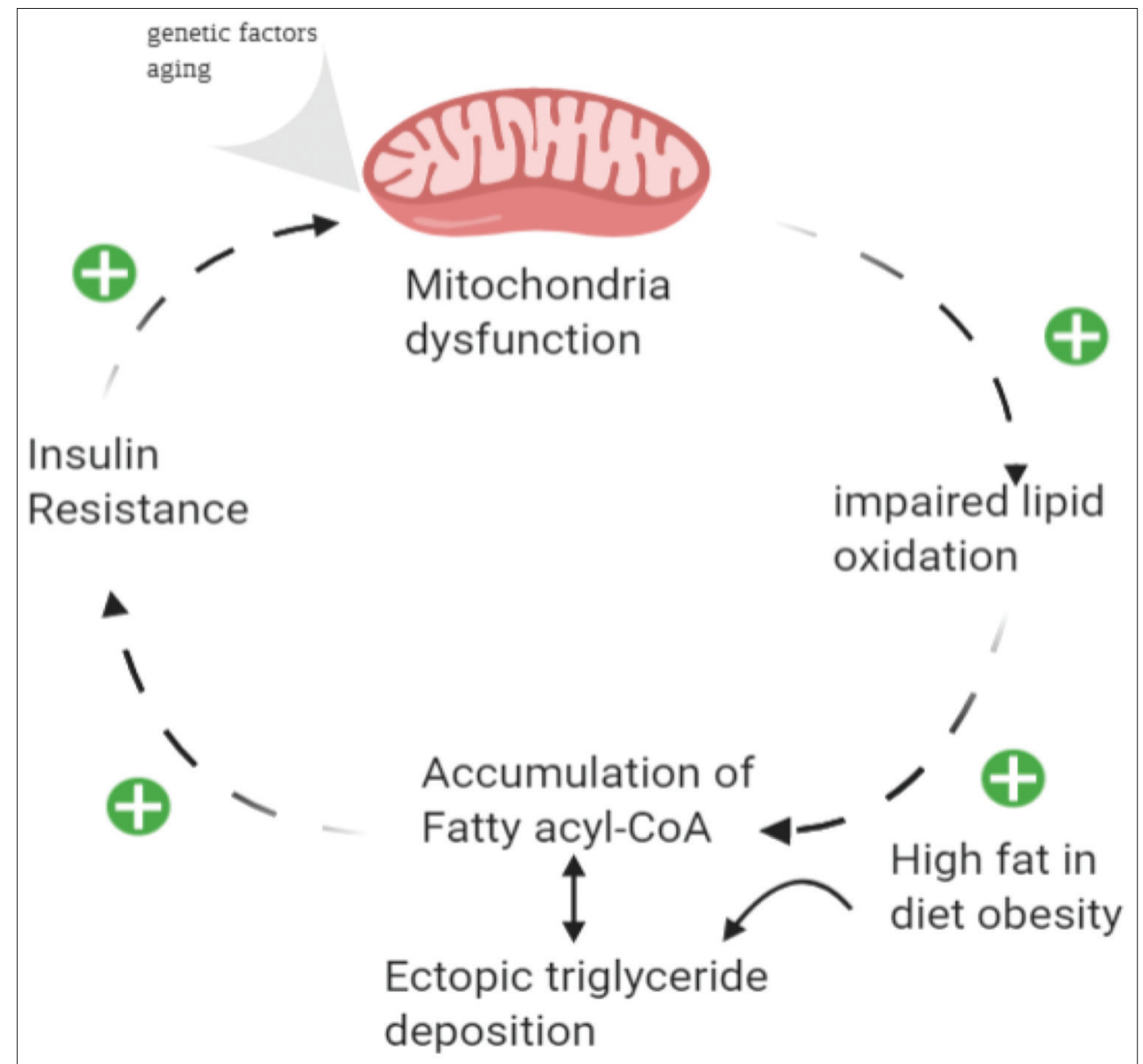

Fig. 6: This cycle is explaining the relation of metabolic syndrome, genetic factors, and obesity in humans. Since obesity is highly associated with insulin resistance causes the "type 2 diabetes mellitus." The insulin resistance correlated with the number and activity of the angiotensin II receptors. Hence, this condition leads to hypertension

catabolism [128,129]. In IR conditions, it has been found to reduce the enzymatic activity of branched-chain alpha-keto acid dehydrogenase complex and hence suppress BCAA catabolism. This shows the positive association between IR and circulating concentrations of BCAAs [129-135]. Besides, IR also alters several other PFAAs, including AAAs, alanine (Ala), proline (Pro), and glycine (Gly) [134] mainly Phe and Tyr. Phe and Tyr determine metabolic syndrome and CVDs (Fig. 4) [135-142].

\section{INFLAMMATION}

The overload of the caloric intake in adipocytes causes an inflammatory response. The inflammation could also cause IR by the direct action of TNF-alpha. The hypertrophied adipocytes are producing a large amount of the MCP-1, which functions as the chemoattractant and enhances the macrophages infiltration in the cells. It contributes to the pro-inflammatory state through the protein kinases JNK1 and MAP4K4. The development of an inflammatory state in adipose tissue associated with skeletal muscle IR (Fig. 5) [143,144]

\section{PPAR- $\gamma$}

The PPAR- $\gamma$ is a member of the PPAR family. It is the nuclear hormone receptor, PPAR- $\gamma$. It is mainly involved in the fatty-acid-controlled differentiation of preadipocytes, nutritional changes in the white adipose tissue regulation of cholesterol metabolism $[145,146]$. The activity of PPAR- $\gamma$ mainly based on inheritance. During the over intake of food, the structural changes occur in the adipocytes form hypertrophy (large size). It leads to decreasing the activity of the PPAR- $\gamma$ on the adipocytes. The accumulation of fat in adipocytes decreases but increases in the plasma levels, which subsequently may lead to IR in the liver, muscle, and adipose tissue (Fig. 6).

\section{DISCUSSION}

We know the development of IR that leads to the cause of T2DM. The sequences of development of IR is by the over intake of fatty acid in the body. As a result of the accumulation of FA-CoA within the myocytes. It leads to improper signaling of the insulin and reduces the level in the myocytes and pancreases beta cells. It combines with genetically reduces the expression of PPAR- $\gamma$ coactivator- 1 , initiates the inflammation process by the activation of the tumor necrotic factor-alpha, and protein kinase C. These alterations lead to further increase the intramyocellular FA-CoA and TG. The sequence of events may develop mitochondrial dysfunction in the sarcolemma outer layers finally develops IR and increasing intramyocellular lipids.

\section{CONCLUSION}

DM is a persistent metabolic disorder which is caused by IR and damage of the pancreas due to socioeconomic, environmental factors. A person was suffering from DM for an extended period they will get macro and microvascular complications in some time; however, we choose our diet wisely and must maintain the physical activities in our daily life as physician advice. If we cannot maintain a proper diet at least take an equal quantity of carbohydrates, fats, and proteins. Dieticians are planning a new diet for T2DM; they try to improve the patient life, and this concept might be helpful for those who are pursuing endocrinology specialization, nursing staff, pharmacists, and other medical departments. 


\section{ACKNOWLEDGMENT}

We would like to thank Dr. Abdul Rahman to inspire us to do this study.

\section{AUTHORS' CONTRIBUTIONS}

All the authors have contributed for review preparation and editing of the manuscript.

\section{CONFLICTS OF INTEREST}

No conflicts of interest.

\section{REFERENCES}

1. World Health Organization. Diabetes. Geneva: World Health Organization; 2020. Available from: https://www.who.int/news-room/ fact-sheets/detail/diabetes. [Last accessed on 2020 Jan 11].

2. Venes D. Taber's Cyclopaedia Medical Dictionary. $21^{\text {st }}$ ed. USA: F A Davis; 2015

3. Ahmed AM. History of diabetes mellitus. Saudi Med J 2002:23:373-8.

4. $\mathrm{Ng}$ E, Vanderloo SE, Geiss L, Johnson JA. Concordance between self-report and a survey-based algorithm for classification of Type 1 and Type 2 diabetes using the 2011 population-based survey on living with chronic diseases in Canada (SLCDC)-Diabetes component. Can J Diabetes 2013;37:249-53.

5. Bellatorre A, Jackson SH, Choi K. Development of the diabetes typology model for discerning Type 2 diabetes mellitus with national survey data. PLoS One 2017;12:e0173103.

6. Urrutia I, Martínez R, Rica I, Martínez de LaPiscina I, GarcíaCastaño A, Aguayo A, et al. Negative autoimmunity in a Spanish pediatric cohort suspected of Type 1 diabetes, could it be monogenic diabetes? PLoS One 2019;14:e0220634.

7. Davis TM, Makepeace AE, Ellard S, Colclough K, Peters K, Hattersley A, et al. The prevalence of monogenic diabetes in Australia: The fremantle diabetes study phase II. Med J Aust 2017;207:344-7.

8. Narayan KM. Type 2 diabetes: Why we are winning the battle but losing the war? 2015 Kelly West Award Lecture. Diabetes Care 2016;39:653-63.

9. Gujral UP, Narayan KM, Kahn SE, Kanaya AM. The relative associations of $\beta$-cell function and insulin sensitivity with glycemic status and incident glycemic progression in migrant Asian Indians in the United States: The MASALA study. J Diabetes Complications 2014;28:45-50.

10. Woodmansey C, McGovern AP, McCullough KA, Whyte MB, Munro NM, Correa AC, et al. Incidence, demographics, and clinical characteristics of diabetes of the exocrine pancreas (Type 3c): A retrospective cohort study. Diabetes Care 2017;40:1486-93.

11. Vftter K. Diabetes mellitus. WHO Technical Report Series 727. 113 Seiten. World Health Organization, Geneva 1985. Preis: 9.00 Sw. Fr. Food Nahrung 1986;30:700

12. Bending J. Book review: Costing diabetes: The case for prevention. IDF task force on diabetes health economics. International Diabetes Federation, Brussels, 1997. Diabet Med 1998;15:705.

13. Seok H, Cha BS. Response: Balsamic vinegar improves high fatinduced beta cell dysfunction via beta cell ABCA1 (Diabetes Metab J 2012;36:275-9). Diabetes Metab J 2012;36:390

14. Jun JE, Lee SE, Lee YB, Jee JH, Bae JC, Jin SM, et al. Increase in serum albumin concentration is associated with prediabetes development and progression to overt diabetes independently of metabolic syndrome. PLoS One 2017;12:e0176209.

15. Narendran P, Estella E, Fourlanos S. Immunology of Type 1 diabetes. QJM 2005;98:547-56.

16. Edelman SV, Morello CM. Strategies for insulin therapy in Type 2 diabetes. South Med J 2005;98:363-71.

17. Weinman EO, Strisower EH, Chaikoff IL. Conversion of fatty acids to carbohydrate; application of isotopes to this problem and role of the Krebs cycle as a synthetic pathway. Physiol Rev 1957;37:252-72.

18. de Figueiredo LF, Schuster S, Kaleta C, Fell DA. Can sugars be produced from fatty acids? A test case for pathway analysis tools. Bioinformatics 2008;24:2615-21.

19. Devendra D, Liu E, Eisenbarth GS. Type 1 diabetes: Recent developments. BMJ 2004;328:750-4.

20. Paschou SA, Papadopoulou-Marketou N, Chrousos GP, KanakaGantenbein C. On Type 1 diabetes mellitus pathogenesis. Endocr Connect 2018;7:R38-46

21. Wherrett DK, Daneman D. Prevention of Type 1 diabetes. Endocrinol
Metab Clin North Am 2009;38:777-90.

22. American Diabetes Association. 7. Diabetes technology: Standards of medical care in diabetes-2019. Diabetes Care 2019;42:S71-80.

23. American Diabetes Association. 2. Classification and diagnosis of diabetes: Standards of medical care in diabetes-2020. Diabetes Care 2020;43:S14-31.

24. American Diabetes Association. 2. Classification and diagnosis of diabetes: Standards of medical care in diabetes-2019. Diabetes Care 2019;42:S13-28.

25. Bloomgarden ZT. American Diabetes Association Annual Meeting, 1999: Insulin action and the development of Type 2 diabetes. Diabetes Care 2000;23:248-52.

26. Turner P. Clinical Pharmacology, seventh edition. Postgrad Med J 1993;69:836.

27. Colagiuri S, Lee CM, Wong TY, Balkau B, Shaw JE, Borch-Johnsen K, et al. Glycemic thresholds for diabetes-specific retinopathy: Implications for diagnostic criteria for diabetes. Diabetes Care 2011;34:145-50

28. Prentki M, Nolan CJ. Islet beta cell failure in Type 2 diabetes. J Clin Invest 2006;116:1802-12.

29. The mysteries of Type 2 diabetes in developing countries. Bull World Health Organ 2016;94:241-2.

30. Jialal I, Singh G. Management of diabetic dyslipidemia: An update. World J Diabetes 2019;10:280-90.

31. American Diabetes Association. Screening for Type 2 diabetes. Diabetes Care 2004;27 Suppl 1:S11-4.

32. Tran HT, Liong S, Lim R, Barker G, Lappas M. Resveratrol ameliorates the chemical and microbial induction of inflammation and insulin resistance in human placenta, adipose tissue and skeletal muscle. PLoS One 2017;12:e173373.

33. Ngala RA, Fondjo LA, Gmagna P, Ghartey FN, Awe MA. Placental peptides metabolism and maternal factors as predictors of risk of gestational diabetes in pregnant women. A case-control study. PLoS One 2017;12:e0181613.

34. Alfadhli EM. Gestational diabetes mellitus. Saudi Med J 2015;36:399-406.

35. Catalano PM, Tyzbir ED, Roman NM, Amini SB, Sims EA. Longitudinal changes in insulin release and insulin resistance in nonobese pregnant women. Am J Obstet Gynecol 1991;165:1667-72.

36. Health Services Executive. Available from: https://www.hse.ie/eng/ health/az/d/diabetes,gestational/diagnosing-gestational-diabetes.html.

37. Barbour LA, McCurdy CE, Hernandez TL, Kirwan JP, Catalano PM, Friedman JE. Cellular mechanisms for insulin resistance in normal pregnancy and gestational diabetes. Diabetes Care 2007;30 Suppl 2:S112-9.

38. Johns EC, Denison FC, Norman JE, Reynolds RM. Gestational diabetes mellitus: Mechanisms, treatment, and complications. Trends Endocrinol Metab 2018;29:743-54.

39. Xiang AH, Peters RK, Trigo E, Kjos SL, Lee WP, Buchanan TA. Multiple metabolic defects during late pregnancy in women at high risk for Type 2 diabetes. Diabetes 1999;48:848-54.

40. Buchanan TA, Metzger BE, Freinkel N, Bergman RN. Insulin sensitivity and B-cell responsiveness to glucose during late pregnancy in lean and moderately obese women with normal glucose tolerance or mild gestational diabetes. Am J Obstet Gynecol 1990;162:1008-14.

41. Damm P, Kühl C, Bertelsen A, Mølsted-Pedersen L. Predictive factors for the development of diabetes in women with previous gestational diabetes mellitus. Am J Obstet Gynecol 1992;167:607-16.

42. Di Cianni G, Miccoli R, Volpe L, Lencioni C, Del Prato S. Intermediate metabolism in normal pregnancy and in gestational diabetes. Diabetes Metab Res Rev 2003;19:259-70.

43. World Health Organization. Diabetes Program, Diabetes Basics. Geneva: World Health Organization. Available from: https://www.who. int/diabetes/action.

44. Committee on Practice Bulletins-Obstetrics. ACOG practice bulletin No. 190: Gestational diabetes mellitus. Obstet Gynecol 2018;131:e49-64.

45. Girdharwal N. The role of psychological well-being in positive human health. Indian J Public Health Res Dev 2019;10:93.

46. American Diabetes Association. (2) Classification and diagnosis of diabetes. Diabetes Care 2015;38 Suppl: S8-16.

47. Diabetes Community, Support, Education, Recipes and Resources Diabetes; 2020. Available from: https://www.diabetes.co.uk. [Last accessed on 2020 Feb 24].

48. Hattersley A, Bruining J, Shield J, Njolstad P, Donaghue K, International Society for Pediatric and Adolescent Diabetes. ISPAD clinical practice consensus guidelines 2006-2007. The diagnosis and 
management of monogenic diabetes in children. Pediatr Diabetes 2006; 7:352-60.

49. Naik R, Brooks-Worrell B, Palmer J. Latent autoimmune diabetes in adults. J Clin Endocrinol Metab 2009;94:4635-44.

50. de la Monte SM, Wands JR. Alzheimer's disease is type 3 diabetesevidence reviewed. J Diabetes Sci Technol 2008;2:1101-13.

51. Type 3 Diabetes: Cross-talk between Differentially Regulated Proteins of Type 2 Diabetes Mellitus and Alzheimer's Disease: Khaytimittal, Ruchijakmola, Mani, Depshikha Pande Katare, Scientific Reports. Switzerland: Springer Nature; 2016.

52. Uday S, Campbell F, Cropper J, Shepherd M. Monogenic diabetes and Type 1 diabetes mellitus: A challenging combination. Pract Diabetes 2014;31:327-30.

53. van der Donk LJ, Fleer J, Sanderman R, Emmelkamp PMG, Links TP, Tovote KA, et al. Is type of depressive symptoms associated with patient-perceived need for professional psychological care in depressed individuals with diabetes? PLoS One 2019;14:e0212304.

54. Cuervo AM, Bergamini E, Brunk UT, Dröge W, Ffrench M, Terman A. Autophagy and aging: The importance of maintaining "clean" cells. Autophagy 2005;1:131-40.

55. Adeniyi AF, Adeleye JO, Adeniyi CY. Diabetes, sexual dysfunction and therapeutic exercise: A 20 year review. Curr Diabetes Rev 2010;6:201-6.

56. Almigbal T. Erectile dysfunction in men with Type 2 diabetes: Is it associated with poor glycemic control? J Mens Health 2019;15:e12-22.

57. USRDS, 2006 ADR: Incidence and Prevalence. Am J Kidney Dis 2007;49:S67-84.

58. Mogensen CE, Christensen CK, Vittinghus E. The stages in diabetic renal disease. With emphasis on the stage of incipient diabetic nephropathy. Diabetes 1983;32 Suppl 2:64-78.

59. Nichols GA, Déruaz-Luyet A, Hauske SJ, Brodovicz KG. The association between estimated glomerular filtration rate, albuminuria, and risk of cardiovascular hospitalizations and all-cause mortality among patients with Type 2 diabetes. J Diabetes Complications 2018;32:291-7.

60. UK Prospective Diabetes Study Group. Tight blood pressure control and risk of macrovascular and microvascular complications in Type 2 diabetes: UKPDS 38. UK prospective diabetes study group. BMJ 1998;317:703-13.

61. Frank RN. Diabetic retinopathy. N Engl J Med 2004;350:48-58.

62. Hirai FE, Tielsch JM, Klein BE, Klein R. Ten-year change in visionrelated quality of life in Type 1 diabetes: Wisconsin epidemiologic study of diabetic retinopathy. Ophthalmology 2011;118:353-8.

63. Abbott CA, Malik RA, van Ross ER, Kulkarni J, Boulton AJ. Prevalence and characteristics of painful diabetic neuropathy in a large communitybased diabetic population in the U.K. Diabetes Care 2011;34:2220-4.

64. Obrosova IG. Diabetic painful and insensate neuropathy: Pathogenesis and potential treatments. Neurotherapeutics 2009;6:638-47.

65. Haffner SM, Lehto S, Rönnemaa T, Pyörälä K, Laakso M. Mortality from coronary heart disease in subjects with Type 2 diabetes and in nondiabetic subjects with and without prior myocardial infarction. N Engl J Med 1998;339:229-34.

66. Laing SP, Swerdlow AJ, Slater SD, Burden AC, Morris A, Waugh NR, et al. Mortality from heart disease in a cohort of 23,000 patients with insulin-treated diabetes. Diabetologia 2003;46:760-5.

67. Domanski M, Mitchell G, Pfeffer M, Neaton JD, Norman J, Svendsen K, et al. Pulse pressure and cardiovascular disease-related mortality: Follow-up study of the multiple risk factor intervention trial (MRFIT). JAMA 2002;287:2677-83.

68. Dunger DB, Sperling MA, Acerini CL, Bohn DJ, Daneman D, Danne TP, et al. ESPE/LWPES consensus statement on diabetic ketoacidosis in children and adolescents. Arch Dis Child 2004;89:188-94

69. Rewers A, Chase HP, Mackenzie T, Walravens P, Roback M, Rewers M, et al. Predictors of acute complications in children with Type 1 diabetes. JAMA 2002;287:2511-8.

70. Savage DB, Petersen KF, Shulman GI. Disordered lipid metabolism and the pathogenesis of insulin resistance. Physiol Rev 2007;87:507-20.

71. Boden G, Cheung P, Stein TP. A recent focusing on studies of lipid effects on insulin resistance in human subjects. Review role of fatty acids in the pathogenesis of insulin resistance and NIDDM. Diabetes 1997;46:3-10

72. Kelley DE, Mokan M, Simoneau JA, Mandarino LJ. Interaction between glucose and free fatty acid metabolism in human skeletal muscle. J Clin Invest 1993;92:91-8.

73. Oakes ND, Bell KS, Furler SM, Camilleri S, Saha AK, Ruderman NB, et al. Diet-induced muscle insulin resistance in rats is ameliorated by acute dietary lipid withdrawal or a single bout of exercise: Parallel relationship between insulin stimulation of glucose uptake and suppression of long-chain fatty acyl-CoA. Diabetes 1997;46:2022-8

74. Goodpaster BH, Thaete FL, Simoneau JA, Kelley DE. Subcutaneous abdominal fat and thigh muscle composition predict insulin sensitivity independently of visceral fat. Diabetes 1997;46:1579-85.

75. Perseghin G, Scifo P, De Cobelli F, Pagliato E, Battezzati A, Arcelloni C, et al. Intramyocellular triglyceride content is a determinant of in vivo insulin resistance in humans: A $1 \mathrm{H}-13 \mathrm{C}$ nuclear magnetic resonance spectroscopy assessment in offspring of Type 2 diabetic parents. Diabetes 1999;48:1600-6.

76. Krssak M, Falk Petersen K, Dresner A, DiPietro L, Vogel SM, Rothman DL, et al. Intramyocellular lipid concentrations are correlated with insulin sensitivity in humans: A $1 \mathrm{H} \mathrm{NMR} \mathrm{spectroscopy} \mathrm{study.}$ Diabetologia 1999;42:113-6.

77. Szczepaniak LS, Babcock EE, Schick F, Dobbins RL, Garg A, Burns DK, et al. Measurement of intracellular triglyceride stores by $\mathrm{H}$ spectroscopy: Validation in vivo. Am J Physiol 1999;276:E977-89.

78. Senn JJ. Toll-like receptor-2 is essential for the development of palmitate-induced insulin resistance in myotubes. $\mathrm{J}$ Biol Chem 2006;281:26865-75.

79. Song MJ, Kim KH, Yoon JM, Kim JB. Activation of Toll-like receptor 4 is associated with insulin resistance in adipocytes. Biochem Biophys Res Commun 2006;346:739-45.

80. Suganami T, Tanimoto-Koyama K, Nishida J, Itoh M, Yuan X, Mizuarai S, et al. Role of the toll-like receptor 4/NF-kappaB pathway in saturated fatty acid-induced inflammatory changes in the interaction between adipocytes and macrophages. Arterioscler Thromb Vasc Biol 2007;27:84-91.

81. Shi H, Kokoeva MV, Inouye K, Tzameli I, Yin H, Flier JS. TLR4 links innate immunity and fatty acid-induced insulin resistance. J Clin Invest 2006;116:3015-25.

82. Tsukumo DM, Carvalho-Filho MA Carvalheira JB, Prada PO, Hirabara SM, Schenka AA, et al. Loss-of-function mutation in Tolllike receptor 4 prevents diet-induced obesity and insulin resistance. Diabetes 2007;56:1986-98.

83. Kahn BB, Flier JS. Obesity and insulin resistance. J Clin Invest 2000;106:473-81.

84. Reaven GM. Banting lecture 1988. Role of insulin resistance in human disease. Diabetes 1988;37:1595-607.

85. Ginsberg HN. Insulin resistance and cardiovascular disease. J Clin Invest 2000;106:453-8

86. Rosen ED, Spiegelman BM. Adipocytes as regulators of energy balance and glucose homeostasis. Nature 2006;444:847-53

87. Kalderon B, Mayorek N, Berry E, Zevit N, Bar-Tana J. Fatty acid cycling in the fasting rat. Am J Physiol Endocrinol Metab 2000;279:E221-7.

88. Smith RE, Horwitz BA. Brown fat and thermogenesis. Physiol Rev 1969;49:330-425.

89. Christianson JL, Nicoloro S, Straubhaar J, Czech MP. Stearoyl-CoA desaturase 2 is required for peroxisome proliferator-activated receptor gamma expression and adipogenesis in cultured 3T3-L1 cells. J Biol Chem 2008;283:2906-16.

90. Frayn KN, Shadid S, Hamlani R, Humphreys SM, Clark ML, Fielding BA, et al. Regulation of fatty acid movement in human adipose tissue in the postabsorptive-to-postprandial transition. Am J Physiol 1994;266:E308-17.

91. Qatanani M, Lazar MA. Mechanisms of obesity-associated insulin resistance: Many choices on the menu. Genes Dev 2007;21:1443-55.

92. Rajala MW, Scherer PE. Minireview: The adipocyte at the crossroads of energy homeostasis, inflammation, and atherosclerosis. Endocrinology 2003; $144: 3765-73$

93. Kershaw EE, Flier JS. Adipose tissue as an endocrine organ. J Clin Endocrinol Metab 2004;89:2548-56.

94. Søvik O, Vestergaard H, Trygstad O, Pedersen O. Studies of insulin resistance in congenital generalized lipodystrophy. Acta Paediatr Suppl 1996;413:29-37.

95. Moitra J, Mason MM, Olive M, Krylov D, Gavrilova O, MarcusSamuels B, et al. Life without white fat: A transgenic mouse. Genes Dev 1998;12:3168-81.

96. Laustsen PG, Michael MD, Crute BE, Cohen SE, Ueki K, Kulkarni RN, et al. Lipoatrophic diabetes in Irs1(-/-)/Irs3(-/-) double knockout mice. Genes Dev 2002;16:3213-22.

97. Shimomura I, Hammer RE, Richardson JA, Ikemoto S, Bashmakov Y, Goldstein JL, et al. Insulin resistance and diabetes mellitus in transgenic mice expressing nuclear SREBP-1c in adipose tissue: Model for congenital generalized lipodystrophy. Genes Dev 1998;12:3182-94.

98. Gregg RE, Brewer HB Jr. The role of apolipoprotein E and lipoprotein receptors in modulating the in vivo metabolism of apolipoprotein B-containing lipoproteins in humans. Clin Chem 1988;34:B28-32. 
99. Zhang SH, Reddick RL, Piedrahita JA, Maeda N. Spontaneous hypercholesterolemia and arterial lesions in mice lacking apolipoprotein E. Science 1992;258:468-71.

100. Mahley RW. Apolipoprotein E: Cholesterol transport protein with expanding role in cell biology. Science 1988;240:622-30.

101. Miyata M, Smith JD. Apolipoprotein E allele-specific antioxidant activity and effects on cytotoxicity by oxidative insults and betaamyloid peptides. Nat Genet 1996;14:55-61.

102. Plump AS, Smith JD, Hayek T, Aalto-Setälä K, Walsh A, Verstuyft JG, et al. Severe hypercholesterolemia and atherosclerosis in apolipoprotein E-deficient mice created by homologous recombination in ES cells. Cell 1992;71:343-53.

103. Blum CB. Dynamics of apolipoprotein E metabolism in humans. J Lipid Res 1982;23:1308-16.

104. Schaefer EJ, Gregg RE, Ghiselli G, Forte TM, Ordovas JM, Zech LA, et al. Familial apolipoprotein E deficiency. J Clin Invest 1986;78:1206-19.

105. Gregg RE, Zech LA, Schaefer EJ, Brewer HB Jr., Type III hyperlipoproteinemia: Defective metabolism of an abnormal apolipoprotein E. Science 1981;211:584-6.

106. Mensenkamp AR, Jong MC, van Goor H, van Luyn MJ, Bloks V, Havinga R, et al. Apolipoprotein E participates in the regulation of very low density lipoprotein-triglyceride secretion by the liver. J Biol Chem 1999;274:35711-8

107. Havel RJ, Kane JP, Kashyap ML. Interchange of apolipoproteins between chylomicrons and high density lipoproteins during alimentary lipemia in man. J Clin Invest 1973;52:32-8.

108. Jeppesen J, Hollenbeck CB, Zhou MY, Coulston AM, Jones C, Chen YD, et al. Relation between insulin resistance, hyperinsulinemia, postheparin plasma lipoprotein lipase activity, and postprandial lipemia. Arterioscler Thromb Vasc Biol 1995;15:320-4.

109. Lin CY, Duan H, Mazzone T. Apolipoprotein E-dependent cholesterol efflux from macrophages: Kinetic study and divergent mechanisms for endogenous versus exogenous apolipoprotein E. J Lipid Res 1999;40:1618-27.

110.Paka L, Kako Y, Obunike JC, Pillarisetti S. Apolipoprotein E containing high density lipoprotein stimulates endothelial production of heparan sulfate rich in biologically active heparin-like domains. A potential mechanism for the anti-atherogenic actions of vascular apolipoprotein e. J Biol Chem 1999;274:4816-23.

111. Riddell DR, Graham A, Owen JS. Apolipoprotein E inhibits platelet aggregation through the L-arginine: Nitric oxide pathway. Implications for vascular disease. J Biol Chem 1997;272:89-95.

112.Bach-Ngohou K, Nazih H, Nazih-Sanderson F, Zaïr Y, Le Carrer D, Krempf M, et al. Negative and independent influence of apolipoprotein $\mathrm{E}$ on C-reactive protein (CRP) concentration in obese adults. Potential anti-inflammatory role of apoE in vivo. Int $\mathrm{J}$ Obes Relat Metab Disord 2001;25:1752-8.

113. Howard BV. Lipoprotein metabolism in diabetes mellitus. J Lipid Res 1987;28:613-28.

114.Garvey WT, Garber AJ, Mechanick JI, Bray GA, Dagogo-Jack S, Einhorn D, et al. American association of clinical endocrinologists and american college of endocrinology position statement on the 2014 advanced framework for a new diagnosis of obesity as a chronic disease. Endocr Pract 2014;20:977-89.

115. Harris MI, Zimmet P. Classification of Mellitus and other categories of glucose intolerance. In: Alberti KG, DeFronzo RA, Zimmet PH, editors. International Textbook of Diabetes Mellitus. Chichester, England: John Willy and Sons; 1992. p. 3-18

116. Sparks LM, Xie H, Koza RA, Mynatt R, Hulver MW, Bray GA, et al. A high-fat diet coordinately downregulates genes required for mitochondrial oxidative phosphorylation in skeletal muscle. Diabetes 2005;54:1926-33.

117. Mootha VK, Lindgren CM, Eriksson KF, Subramanian A, Sihag S, Lehar J, et al. PGC-1alpha-responsive genes involved in oxidative phosphorylation are coordinately downregulated in human diabetes. Nat Genet 2003;34:267-73.

118.Kahn SE. The relative contributions of insulin resistance and beta-cell dysfunction to the pathophysiology of Type 2 diabetes. Diabetologia 2003;46:3-19

119. Clee SM, Attie AD. The genetic landscape of Type 2 diabetes in mice. Endocr Rev 2007;28:48-83.

120. Rhodes CJ. Type 2 diabetes-a matter of beta-cell life and death? Science 2005;307:380-4.

121. Patti ME, Butte AJ, Crunkhorn S, Cusi K, Berria R, Kashyap S, et al. Coordinated reduction of genes of oxidative metabolism in humans with insulin resistance and diabetes: Potential role of PGC1 and NRF1.
Proc Natl Acad Sci U S A 2003;100:8466-71.

122. Patti ME, Kahn BB. Nutrient sensor links obesity with diabetes risk. Nat Med 2004; 10:1049-50

123. Tremblay F, Krebs M, Dombrowski L, Brehm A, Bernroider E, Roth E, et al. Overactivation of S6 kinase 1 as a cause of human insulin resistance during increased amino acid availability. Diabetes 2005;54:2674-84

124. Sims EA, Danforth E Jr, Horton ES, Bray GA, Glennon JA, Salans LB. Endocrine and metabolic effects of experimental obesity in man. Recent Prog Horm Res 1973;29:457-96.

125. Freidenberg GR, Reichart D, Olefsky JM, Henry RR. Reversibility of defective adipocyte insulin receptor kinase activity in non-insulindependent diabetes mellitus. Effect of weight loss. J Clin Invest 1988;82:1398-406

126. Butler AE, Janson J, Bonner-Weir S, Ritzel R, Rizza RA, Butler PC. Beta-cell deficit and increased beta-cell apoptosis in humans with Type 2 diabetes. Diabetes 2003;52:102-10.

127. Costeas PA, Chinsky JM. Effects of insulin on the regulation of branched-chain alpha-keto acid dehydrogenase E1 alpha subunit gene expression. Biochem J 1996;318 (Pt 1):85-92.

128. Lackey DE, Lynch CJ, Olson KC, Mostaedi R, Ali M, Smith WH, et al. Regulation of adipose branched-chain amino acid catabolism enzyme expression and cross-adipose amino acid flux in human obesity. Am J Physiol Endocrinol Metab 2013;304:E1175-87.

129. Newgard CB, An J, Bain JR, Muehlbauer MJ, Stevens RD, Lien LF, et al. A branched-chain amino acid-related metabolic signature that differentiates obese and lean humans and contributes to insulin resistance. Cell Metab 2009;9:311-26.

130. Shah SH, Crosslin DR, Haynes CS, Nelson S, Turer CB, Stevens RD, et al. Branched-chain amino acid levels are associated with improvement in insulin resistance with weight loss. Diabetologia 2012;55:321-30.

131. McCormack SE, Shaham O, McCarthy MA, Deik AA, Wang TJ, Gerszten RE, et al. Circulating branched-chain amino acid concentrations are associated with obesity and future insulin resistance in children and adolescents. Pediatr Obes 2013;8:52-61.

132. Würtz $P$, Soininen $P$, Kangas AJ, Rönnemaa T, Lehtimäki T, Kähönen $\mathrm{M}$, et al. Branched-chain and aromatic amino acids are predictors of insulin resistance in young adults. Diabetes Care 2013;36:648-55

133. Tai ES, Tan ML, Stevens RD, Low YL, Muehlbauer MJ, Goh DL, et al. Insulin resistance is associated with a metabolic profile of altered protein metabolism in Chinese and Asian-Indian men. Diabetologia 2010;53:757-67

134. Wang TJ, Larson MG, Vasan RS, Cheng S, Rhee EP, McCabe E, et al. Metabolite profiles and the risk of developing diabetes. Nat Med 2011;17:448-53.

135. Magnusson M, Lewis GD, Ericson U, Orho-Melander M, Hedblad B, Engström $\mathrm{G}$, et al. A diabetes-predictive amino acid score and future cardiovascular disease. Eur Heart J 2013;34:1982-9.

136. Würtz P, Mäkinen VP, Soininen P, Kangas AJ, Tukiainen T, Kettunen J, et al. Metabolic signatures of insulin resistance in 7,098 young adults. Diabetes 2012;61:1372-80

137. Yamada C, Kondo M, Kishimoto N, Shibata T, Nagai Y, Imanishi T, et al. Association between insulin resistance and plasma amino acid profile in non-diabetic Japanese subjects. J Diabetes Investig 2015;6:408-15.

138. Martin FP, Montoliu I, Collino S, Scherer M, Guy P, Tavazzi I, et al. Topographical body fat distribution links to amino acid and lipid metabolism in healthy obese women [corrected]. PLoS One 2013;8:e73445.

139. Wang-Sattler R, Yu Z, Herder C, Messias AC, Floegel A, He Y, et al. Novel biomarkers for pre-diabetes identified by metabolomics. Mol Syst Biol 2012;8:615.

140. Yamakado M, Tanaka T, Nagao K, Imaizumi A, Komatsu M, Daimon T, et al. Plasma amino acid profile associated with fatty liver disease and co-occurrence of metabolic risk factors. Sci Rep 2017;7:14485.

141. Mäntyselkä P, Niskanen L, Kautiainen H, Saltevo J, Würtz P, Soininen $\mathrm{P}$, et al. Cross-sectional and longitudinal associations of circulating omega-3 and omega-6 fatty acids with lipoprotein particle concentrations and sizes: Population-based cohort study with 6-year follow-up. Lipids Health Dis 2014;13:28

142. Shulman GI. Cellular mechanisms of insulin resistance. J Clin Invest 2000;106:171-6.

143. Biddinger SB, Kahn CR. From mice to men: Insights into the insulin resistance syndromes. Annu Rev Physiol 2006;68:123-58.

144. Bastie C, Luquet S, Holst D, Jehl-Pietri C, Grimaldi PA. Alterations of peroxisome proliferator-activated receptor delta activity affect fatty acid- 
controlled adipose differentiation. J Biol Chem 2000;275:38768-73.

145. Leibowitz MD, Fiévet C, Hennuyer N, Peinado-Onsurbe J, Duez H, Bergera J, et al. Activation of PPARdelta alters lipid metabolism in $\mathrm{db} /$ db mice. FEBS Lett 2000;473:333-6.
146. Oliver WR Jr., Shenk JL, Snaith MR, Russell CS, Plunket KD, Bodkin NL, et al. A selective peroxisome proliferator-activated receptor delta agonist promotes reverse cholesterol transport. Proc Natl Acad Sci U S A 2001;98:5306-11. 